Volume 1, Issue 2, pages 147-168

\title{
Morphological Map Analysis in Design Cashew Sheller (Kacip) as a Creative Process to Produce Design Concept
}

\author{
Bertha Bintari Wahyujati \\ Department of Mechatronics Product Design, \\ Politeknik Mekatronika Sanata Dharma, Yogyakarta, Indonesia \\ Corresponding Author: bertha.bintariwahyujati@gmail.com
}

(Received 29-05-2019; Revised 17-10-2019; Accepted 17-10-2019)

\begin{abstract}
The design of cashew nut or cashew nut sheller uses appropriate or low technoshelly with consideration of low cost for tool material. This pengkacip tool will be used at Ngudi Koyo, Imogiri, Bantul, Yogyakarta. Cashew shell peeler or cippling device as a result of the design is a modification of the existing cashew shell peeler. Some parts of the existing tool are applied to several modified parts, namely the lever mechanism, picking knife, or lever knife. This paper will discuss the method of selecting a suppressor, lever and picking system on a tool using the morphological chart analysis method. Morphological charts will produce alternative designs for cashew nut peeler. The selection of alternative designs will be carried out by analyzing the results of testing in a technical mechanism, material strength, and alternative design quality values. Testing of alternative technical systems mechanisms is done by comparing the mechanical systems of existing tools. The size of the tool uses the anthropometric measurements of the female operator's body, because the operators in the Ngudi Koyo UKM are all women. The tool size adjustment
\end{abstract}




\section{International Journal of Applied Sciences and Smart Technologies}

Volume 1, Issue 2, pages 147-168

p-ISSN 2655-8564, e-ISSN 2685-9432

will provide to work more comfortable and increase efficiency. Quality testing in addition which is using standard anthropometric standards, will be tested for quality of ease to maintenance, ease to mobility, cleanability, neat, simple and safety tool.

Keywords: effective technoshelly, low technoshelly tool, security, design alternative testing

\section{Introduction}

UKM Ngudi Koyo Production System is a production that depends on supply and orders. Production cannot be carried out continuously because the supply of cashew nuts is not always in same quantity and quality, also because cashews only can be harvesting in October per year. These unstabil quantities cause the production have to be flexible in production system. Production depends on the order, availability of material and availability of time of the worker. The character of this production system causes production equipment not always to be operate. Equipment that not be operated will be stored in the UKM's production house, so the equipment needs are concise, do not require a big space and portable [1].

The production operators at Ngudi Koyo UKM are all farmers, so the cashew nut production business is a side business. As a side business, the production of cashew nuts is expected to be done on the free time when all farming work is completed done. The workers who are all woman work on the process of stripping the shell, stripping the epidermis and packing the cashews. Workmanship is often taken home because of the flexible work time and workmanship that can be taken to work other jobs at home. Therefore, a sheller that has easy to move places becomes a very important.

Flexibility also needed beside of the need of construction strength tools, including the possibility of working using this tool using their own table, easy to operate, and can be used at any time. Tools that have the capacity in accordance with the capabilities of each worker can be owned as a personal tool.

With the limitations of the specifications as needed for the cashew nut sheller, the design method that will be applied will be the analyzing method of morphological chart. 


\section{International Journal of Applied Sciences and Smart Technologies}

Volume 1, Issue 2, pages 147-168

p-ISSN 2655-8564, e-ISSN 2685-9432

Morphological charts will facilitate selection of components in each part of the tool. Thus, after getting alternative designs, it will be analyzed to determine the best alternative choice for the design to be improved. The cashew nut sheller is expected to be used for small-scale production, empowering operators, improving the value in production of cashew nuts at UKM Ngudi Koyo.

\section{Technical Data and Specifications of Cashew Nut Spindles}

Cashew nut is a fruit from Cashew tree. Cashew plant with the Latin name Anacaridium occidentale $\mathrm{L}$ is a plant that lives in dry areas, and has little rainfall. The physical cashew fruit is a fake fruit as an enlargement of the fruit stalk. The fruit which is called as cashew nuts, located at the tip of the fruit. Cashew trees are filling plants between fields and villages of the villagers. One cashew tree can produce an average of about 1 quintal of cashew.

Cashew trees only have one harvest cycle season; in August, cashew trees start flowering, the process until the fruit ready for harvest is in October. Harvest cashew fruits are intended to harvest cashew nuts. The cashew nuts then will be dried under the sun rays for about one week. Drying the nuts intended for storing raw materials in production houses. Cashew nuts in perfect dried cashew can be stored for last more than a year. The production process is usually started before the holidays based on orders. The storage process will be important before the cashew through the next process, which is the separation of nuts from the shells using kacip. 


\section{International Journal of Applied Sciences and Smart Technologies}

Volume 1, Issue 2, pages 147-168

p-ISSN 2655-8564, e-ISSN 2685-9432

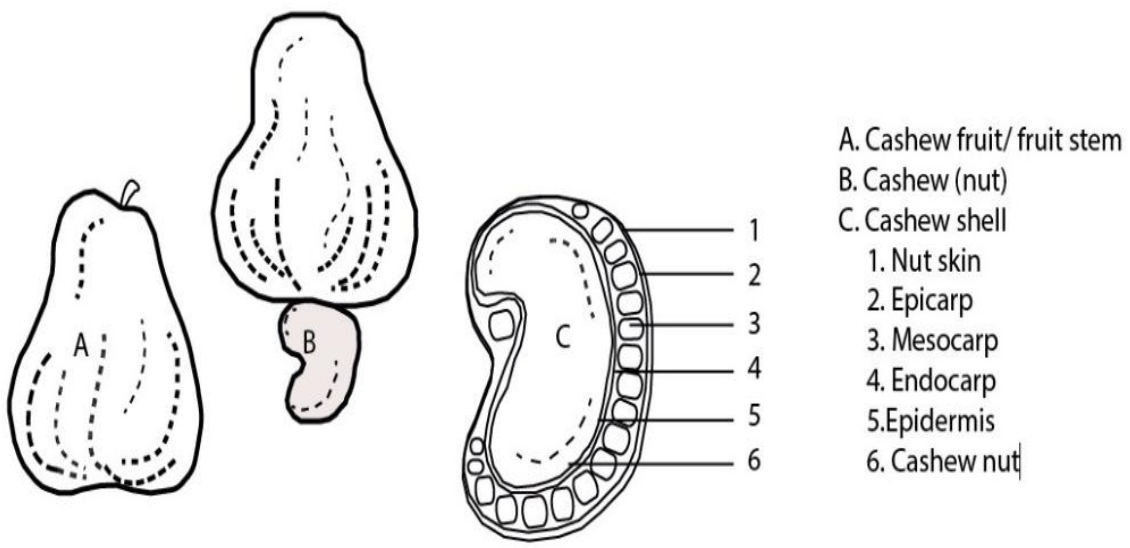

Figure 1. Cashew and its parts [2]

Cashew shells have hard skin called the Pericarp consisting of three layers, namely: the epicarp layer, the mesocarp layer, and the endocarp layer. Epicarp is the outermost skin, the outermost layer that has hard and tough properties. Mesocarp is the middle layer which has the thickest layer of the three layers of skin. In the Mesocarp layer there are conduits that drain liquid CNSL (Cashew Nut Shell Liquid) which are sticky and toxic. This liquid could irritate skin, and is toxic to be eaten. Endocarp is a soft inner layer [2]. These all are illustrated in Figure 1, where A shows cashew fruit, it is also a fruit stem, B shows cashew's nut, and C shows cashew shell and its parts: 1. nut skin, 2. epicarp, 3. mesocarp, 4. endocarp, 5. epidermis, and 6. cashew nut.

Data of cashew shells measurements will be used to design the sheller include the average size of cashew shells, the depth of the skin that can be penetrated by the blade without breaking the cashew nuts, the speed of knife pressure, and the blade pressure to the cashew nut also the direction which is most effective to get the cashew nuts. Look at the Table 1 below:

Table 1. Results of measurement and weighing of weights of cashew nuts [2]

\begin{tabular}{ccccccc}
\hline Criteria & A & B & C & D & E & F \\
\hline Length $(\mathrm{mm})$ & 53,00 & 40,00 & 34,00 & 29,00 & 27,00 & 19,00 \\
Width $(\mathrm{mm})$ & 32,00 & 33,00 & 22,00 & 20,00 & 19,00 & 14,00 \\
Thickness (mm) & 17,00 & 23,00 & 14,00 & 17,00 & 11,00 & 8,00 \\
Weight (gr) & 15,00 & 15,00 & 7,00 & 5,30 & 3,80 & 1,23 \\
\hline
\end{tabular}




\section{International Journal of Applied Sciences and Smart Technologies}

Volume 1, Issue 2, pages 147-168

p-ISSN 2655-8564, e-ISSN 2685-9432

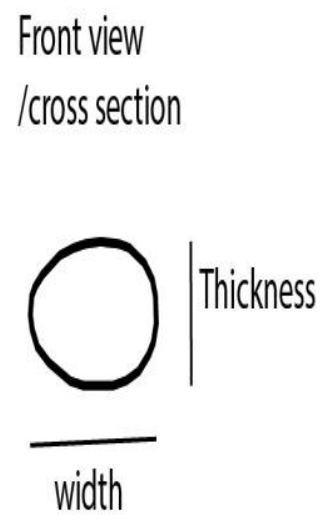

Upview

/cross section

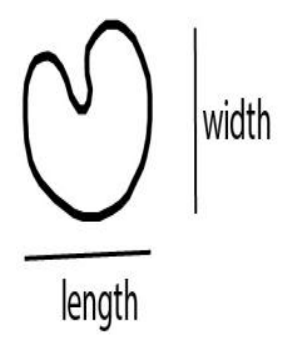

Figure 2. Position of measurement cashew shells [3]

The data is used to determine the optimal size for cashew nut clamp. The optimal size must be able to accommodate each size, so it must be considered a factor of flexibility to clamp different sizes of cashew. The use of a system presses towards the outer shell of the log to penetrate the maximum layer of the mesocarp, or the middle layer which is porous and contains liquid CNSL (Cashew Nut Shell Liquid). The data needed is about the average depth of the gelindong from the outermost layer of the skin to the middle layer, to determine the maximum depth of the knife piercing the cashew nut. The depth of the blade will determine the force used to press the piercing blade.

From the data it was found that the average cashew size was divided into 6 criteria for cashew nuts. The size of the clamp will be selected flexible clamp that can accommodate 6 types of cashew size. From the compressive velocity data and the average depth of the knife, a speed of $250 \mathrm{~m} / \mathrm{sec}$ can be obtained which produces a $24 \mathrm{~mm}$ blade depth with a compressive force $4.84 \mathrm{~N} / \mathrm{m}$. This compression force will determine the type of spring and spring material to be used. In Table 2 and Table 3 we can see the speed of emphasis of cashew nut blades and relationship between the compressive force charged and size cashew nut. We can also see the postition of compressing cashew logs in Figure 2. The data used to determine the optimal size for cashew nut clamp. The optimal size must be able to accommodate each size, so it must be considered the factor of flexibility to clamp different sizes of cashew. The use of a 


\section{International Journal of Applied Sciences and Smart Technologies}

Volume 1, Issue 2, pages 147-168

p-ISSN 2655-8564, e-ISSN 2685-9432

system presses towards the outer shell of the shell to penetrate the maximum layer of the mesocarp, or the middle layer which is porous and contains liquid CNSL (Cashew Nut Shell Liquid). The average depth of the shell from the outermost layer of the skin to the middle layer, to determine the maximum depth of the knife piercing the cashew nut. The depth of the blade will determine the force used to press the piercing blade.

The cashew size was divided into 6 criteria for cashew nuts. The size of the clamp will be selected which can be flexible that can accommodate 6 types of cashew size. From the compressive velocity data and the average depth of the knife, a speed of $250 \mathrm{~m} / \mathrm{sec}$ can be obtained which produces a $24 \mathrm{~mm}$ blade depth with a compressive force $4.84 \mathrm{~N} / \mathrm{m}$. This compression force will determine the type of spring and spring material to be used. Look at the Table 2 and Table 3 below:

Table 2. Speed of emphasis for the depth of cashew nut blades [2]

\begin{tabular}{ccc}
\hline Press speed (m / sec) & Average knife depth (mm) & Press force \\
\hline 1.67 & 23,70 & 4,84 \\
2.50 & 24,00 & 4,84 \\
3.33 & 24,00 & 4,90 \\
\hline
\end{tabular}

Table 3. Relationship between the compressive force charged (kgf) to the cashew nut and the size changes that occur [2]

\begin{tabular}{lccc}
\hline No & Maximum load & $\begin{array}{c}\text { Average compressive } \\
\text { force (kgf) }\end{array}$ & $\begin{array}{c}\text { Reduced size in } \\
\text { shape (mm) }\end{array}$ \\
\hline 1. & Pressure on the thick side & 48,40 & 4,70 \\
2 & Pressure on the long side & 64,70 & 11,30 \\
3. & Pressure on width & 49,20 & 7,80 \\
\hline
\end{tabular}

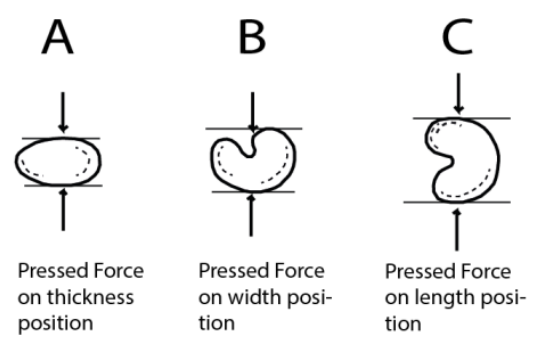

Figure 3. Position of compressing cashew logs [2] 


\section{International Journal of Applied Sciences and Smart Technologies}

Volume 1, Issue 2, pages 147-168

p-ISSN 2655-8564, e-ISSN 2685-9432

Before get pressure from the knife, position of the cashew nut should be in the middle of the cashew nuts. It found in this position, the cashew are not too deformed due to pressure. Deformation of a pressure that is too large will cause the cashews be splitted because of knife pressure when piercing the shell. The position to get the optimal pressure and be able to open the shell is position $\mathrm{B}$. The advantages of this position is because the shape of the cashew nut which has an inner basin in its shape. To open the shell without made nut be splitted, the tip of the blade must be shaped as a triangle to pierce the part of the cashew basin. Some positions of compressing cashew logs are shown in Figure 3.

The force of pressing the knife into the cashew nut will determine the shape of the blade tip chosen. The position of pressing the knife to pierce the cashew nut, and the position of the cashew nut against the blade horizontally or vertically will determine the amount of pressure on the blade given. The position of the cashew nut from its shape determines the size of the blade. The depth of the blade is determined by the maximum depth until the middle layer so that the blade shape should be tapered at the end. After the blade pierces the cashew nut then the blade is tilted as a lever end to separate the cashew nuts from the shell.
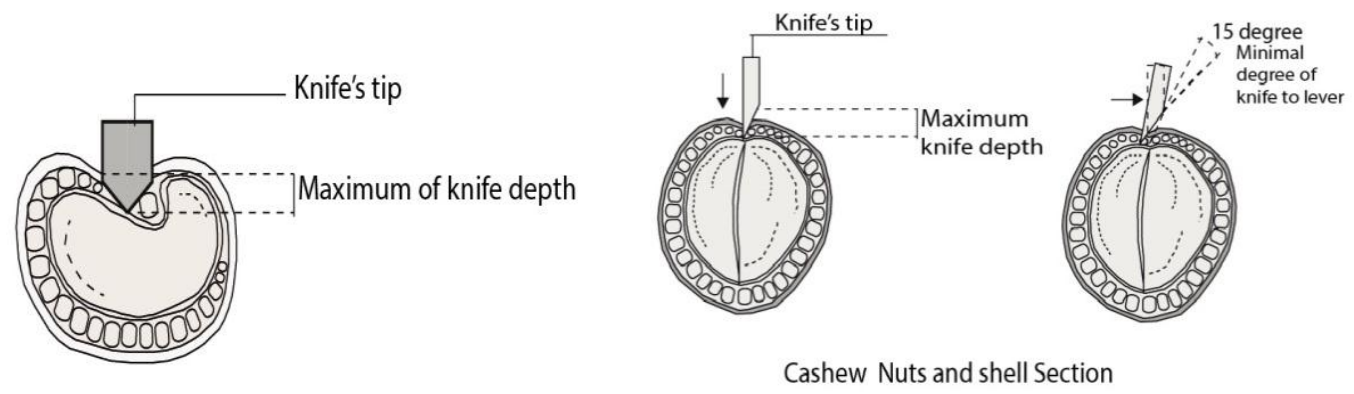

Figure 4. Maximum depth of blade

The slope of the blade is to leverage at a minimum of 15-20 degrees. The magnitude of the lever angle will affect the leverage or torque applied to the blade. Illustrations are given in Figure 4, where details are presented in Table 4. 


\section{International Journal of Applied Sciences and Smart Technologies}

Volume 1, Issue 2, pages 147-168

p-ISSN 2655-8564, e-ISSN 2685-9432

Table 4. Relationship between Torque magnitude and torsional angle to release cashew nuts from the skin [2]

\begin{tabular}{cc}
\hline $\begin{array}{c}\text { Size angle of } \\
\text { suppressor (degree) }\end{array}$ & $\begin{array}{c}\text { Average maximum torque } \\
\text { (kgf.cm) }\end{array}$ \\
\hline 15 & 28,00 \\
20 & 29,20 \\
45 & 28,30 \\
\hline
\end{tabular}

The production process at Ngudi Koyo UKM can not finish in one day process. Work carried out separately in each employee's house. The production process will be handling as separately works. Worker do the job at home to peeling the spindles, and the skin of the cashews.

Within 1 day, workers are usually able to peel cashew nuts as much as $7 \mathrm{~kg}$ of cashew nuts. The salary received by workers is $R p .7000 / \mathrm{kg}$. Cashew which has been peeled dried to make easier to stripping of epidermis. Cashews will be preparate as raw cashew nuts and fried cashews. Cashew nuts for raw orders will be dried before ready to be packaged. While the order of fried cashew nuts processed in frying process.

Raw cashew nuts will be divided into 3 quality criteria for cashew nuts based on customer orders, there are whole cashew nuts and split cashew nuts which will be packaged separated will be sell at price $R p .120000 / \mathrm{kg}$. Meanwhile, crushed cashew nuts are sold at a price between $R p .60,000-R p .80,000$. The sale of mixed cashew nuts consists of whole cashew nuts, split cashews and crushed cashew nuts sold at prices ranging from $R p .80000$ to $R p .90,000$.

Cashew nut sheller is called kacip. Kacip is a tool with a knife modified with a wooden frame, measuring 30 centimeters long. This kacip wood tool consists of a knife that has a wood and pressing knife blade. Cashew shell is placed under the blade inside the nut holder, the cashew nut is held with the thumb and forefinger. The position of the other fingers holds the cashew nut that has not been peeled. Stripping of the cashew nuts is by putting cashew nuts one by one. Stripping must be carefully because raw cashew has liquid sap which is very irritating. The selling price of whole cashew as good quality is higher, the stripping of cashew nut should not splitted into two parts. The cashew nut shelling equipment in recent time only owned by a few workers, because not everyone has the expertise to peel the cashew nut with good quality result. 


\section{International Journal of Applied Sciences and Smart Technologies}

Volume 1, Issue 2, pages 147-168

p-ISSN 2655-8564, e-ISSN 2685-9432

\section{Morphological Chart Analysis Method}

The method of designing the cashew nut sheller is to mapping the part of the important part of the sheller based on the reference of the existing tool. The method of analyzing morphological maps is carried out by step-determining the technical criteria and mechanisms, material criteria, strength criteria, quality criteria. These criteria make it easy to set and sort the appropriate components. The level of criteria used for the whole tool is divided into parts. The parts of the tool are as follows: buffer construction parts, lever parts, knife parts, tool holder parts and cashew nuts. All parts of the tool are then given alternatives to then be combined into a concept of alternative tools. The alternative concept is then described thoroughly. Of all alternatives will be analyzed using an analysis of the criteria of technical specifications and mechanisms, the strength of the material and the quality determined based on the criteria of the specifications that are according to the needs of the tool.

\section{Technical Criteria and Mechanisms}

Technical analysis is a functional and technical analysis related to the mechanism for the peeler system. In addition, technical analysis covers the analysis of the structure construction of the constructor of the peeler [4].

\subsection{Technical Specifications}

The existing cashew sheller is called kacip. The tool is made of one blade with a slit in the side of the knife. Laying cashew logs one by one held with fingers without safety. Incorrect pressing of the knife causes the skin not to be peeled or the cashew split into two. Therefore not everyone can peel the cashew using kacip.

For the design of cashew nut sheller, use the kacip reference. Tools modified from frames that were previously made of wood, replaced with metal. The blade is replaced by using stainless steel. Stainless steel blade chosed because the material safe to use for food and food ingredients. The price of this material is more expensive than iron material. The knife is designed as a flat plate with the tip of a pointed triangle blade with an angle 15-20 degree. The type of knife edge we can see on Figure 5. 


\section{International Journal of Applied Sciences and Smart Technologies}

Volume 1, Issue 2, pages 147-168

p-ISSN 2655-8564, e-ISSN 2685-9432

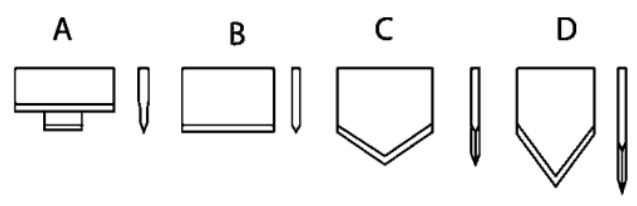

Figure 5. Type of knife edge

The lever system and presses on the blade use hinges that are retained with a spring. The place for laying cashew nuts uses a clamp system as a position guard. Placement of cashew remains one by one using a clamp that can be moved towards the blade. Difficulty in placement if done in large volumes poured because the shape of the cashew $\operatorname{logs}$ is not uniform, the size is different. The position of the cashew nut to be peeled must be on the back of the cashew nut. The directional lever system perpendicular to the direction of stabbing is intended to leverage the cashew seeds out of their shells. Lever knives use a maximum torque of 20 so that there is a minimum formed angle of 15 degrees.

Mohamad Saldin Wibowo (IPB, 2011) examined the size of local Indonesian cashews and obtained three lengths of cashew nut cashew fruit. The size is to determine the size of the blade to be used on the cashew nut peeler [5]. The blade is determined from the size of the cashew log data, namely $33 \mathrm{~mm}$ long blade for piercing large cashew logs $(28.50-32.15 \mathrm{~mm}), 29 \mathrm{~mm}$ long blade for piercing medium sized cashew nuts $(24.80-28.45 \mathrm{~mm}), 25 \mathrm{~mm}$ long blade for piercing small size cashew nuts $(21.05-24.75 \mathrm{~mm})$. The three types of knife sizes are taken; the average size is $(29 \mathrm{~mm})$ determining the size of the blade allows accommodating the piercing function of the three criteria for the size of the cashew logs.

\subsection{Morphological Chart}

The method of morphological maps requires comparison of tools from existing tools, judging by their weaknesses and strengths so that they can be used as new references and innovations [6]. Innovations in this regard cover modifications. We can see this at Table 5 


\section{International Journal of Applied Sciences and Smart Technologies}

Volume 1, Issue 2, pages 147-168

p-ISSN 2655-8564, e-ISSN 2685-9432

Table 5. Analysis of existing tools

\begin{tabular}{|c|c|c|c|}
\hline Tool Type & $:: 100$ & & \\
\hline \multirow[t]{2}{*}{ Tool's name } & $\begin{array}{l}\text { Kacip } \\
\text { (wooden sheller) }\end{array}$ & Kacip flat plate & $\begin{array}{l}\text { Kacip ripper } \\
\text { clamps }\end{array}$ \\
\hline & $\begin{array}{l}\text { The blade on the whole } \\
\text { kacip is made to match }\end{array}$ & With this complete & The cashew coil is \\
\hline Operational & $\begin{array}{l}\text { the natural shape of the } \\
\text { cashew nut so that the } \\
\text { blade only splits the skin } \\
\text { several millimeters thick } \\
\text { as the skin is cut. After } \\
\text { the skin is split, the } \\
\text { cashew seeds are } \\
\text { removed using a knife or } \\
\text { flat nail }\end{array}$ & $\begin{array}{l}\text { kacip, } 8 \mathrm{~kg} \text { of cashew } \\
\text { nuts are obtained per } \\
\text { person per day (one day } \\
8 \text { hours work) with a } \\
\text { capacity of } 70 \% \text { whole } \\
\text { seeds and } 30 \% \text { fractions } \\
\text { consisting of halves, } \\
\text { fragments, groats and } \\
\text { dust }\end{array}$ & $\begin{array}{l}\text { placed in the } \\
\text { clamp gap then } \\
\text { pressed like a } \\
\text { hand-held motion }\end{array}$ \\
\hline $\begin{array}{l}\text { working } \\
\text { deficiency }\end{array}$ & $\begin{array}{l}\text { Cashew shell are placed } \\
\text { one by one and held by } \\
\text { hand, maybe the cashew } \\
\text { is split very high, need } \\
\text { trained people, cashew } \\
\text { must still be gouged with } \\
\text { other tools from the shell } \\
\text { of the shell }\end{array}$ & $\begin{array}{l}\text { Cashew shell are still } \\
\text { placed one by one on a } \\
\text { jagged base, still not } \\
\text { safe }\end{array}$ & $\begin{array}{l}\text { Cashew sponges } \\
\text { are still placed one } \\
\text { by one, the } \\
\text { pressure must be } \\
\text { careful, the } \\
\text { possibility of } \\
\text { lettuce and nuts } \\
\text { split. }\end{array}$ \\
\hline
\end{tabular}

The analysis of work methods or functional analysis of the tools observed above, the lack of tools to find the best solution for modification so that it will be more optimal. The optimal standard results that are referenced are fewer split cashew nuts. In the functional analysis found similarities in the working principle, namely the first step is to stab cashew nuts and then pick out the cashew seeds. The design of the cashew nut peeler consists of the following sections 


\section{International Journal of Applied Sciences and Smart Technologies}

Volume 1, Issue 2, pages 147-168

p-ISSN 2655-8564, e-ISSN 2685-9432

a. Supporting framework

The supporting frame is a frame that serves to support the entire cashew shelling unit. The supporting frame also serves to resist the forces that occur due to the transmission of force and the weight of the load.

b. Lever handle

The lever is an arm for channeling the pressure force and then leveres on the blade to stab and gouge the cashew nuts.

c. Spring

The spring can reduce vibrations due to the movement of the lever when stabbing and gouging the cashew nut shell. The position of the handle will return to its original position by using a spring after the lever is moved. The spring can be used to regulate and control the compressive force so that the distance of the blade press can be controlled to adjust to the cashew log posture to be peeled. The spring also functions to reduce the pressure applied by the operator.

d. Knife

This knife functions when the blade pierces the shell of the cashew nut and to bring it up to release the cashew nuts from the cashew seeds. The edge of the paring knife has a blade that has a 15 o tip and a smooth angle so that it can pierce the cashew nut. The tip of the pointed blade will be more in line with the size of the different cashew nuts, because it can pierce according to its posture. The tip of the pointed blade accommodates the shape of the cashew nut overdraft. This is so that the blade can pierce the skin at the desired position and depth so that the cashew seeds remain intact.

\subsection{Ergonomic Analysis}

Working comfort, the ease of operating tools and security when operating tools is an important criterias. Working comfort is determined by the compatibility between work position and tool size. Ease of operation in terms of the mechanism of the tool and ease of use, it is not complicated, easy to learn and use energy as lightly as possible. While the safety of work is viewed from safety against accidents caused by device errors, operator accident and equipment damage. 


\section{International Journal of Applied Sciences and Smart Technologies}

Volume 1, Issue 2, pages 147-168

p-ISSN 2655-8564, e-ISSN 2685-9432

Ergonomics as one of the considerations for the design criteria for the design of the peeler is determined from the comfort side of the operator working while sitting, rarely hands when reaching, holding, rotating and security aspects against the danger of cutting [7].

The anthropometric data used with the data subjects were women aged 20 years - 47 years. The measured anthropometry is the female operator who works for the Ngudi Koyo UKM. From the measurements obtained anthropometric data as follows in Table 6 and Figure 6 :

Table 6. Anthropometric data of female workers [5]

\begin{tabular}{llcccc}
\hline No. & Body Dimension & $5 \%(\mathrm{~mm})$ & $X(\mathrm{~mm})$ & $95 \%(\mathrm{~mm})$ & $S D$ \\
\hline 1 & Eye Height & 1279 & 1388 & 1497 & 66 \\
2 & Shoulder height & 1130 & 1260 & 1389 & 79 \\
3 & Height of eye in sitting position & 576 & 650 & 723 & 45 \\
4 & Shoulder height in a sitting position & 462 & 515 & 569 & 33 \\
5 & Elbow height in a sitting position & 161 & 186 & 211 & 15 \\
6 & Thigh thick & 87 & 110 & 133 & 14 \\
7 & Distance from the buttocks to the knees & 422 & 508 & 595 & 53 \\
8 & Distance from folding knees to buttocks & 388 & 429 & 470 & 25 \\
9 & Knee height & 417 & 458 & 499 & 25 \\
10 & Knee height & 357 & 395 & 433 & 23 \\
11 & Pelvic width & 282 & 328 & 374 & 28 \\
12 & Distance from elbow to fingertip & 258 & 297 & 337 & 24 \\
13 & Front hand grip distance & 543 & 596 & 649 & 32 \\
\hline
\end{tabular}

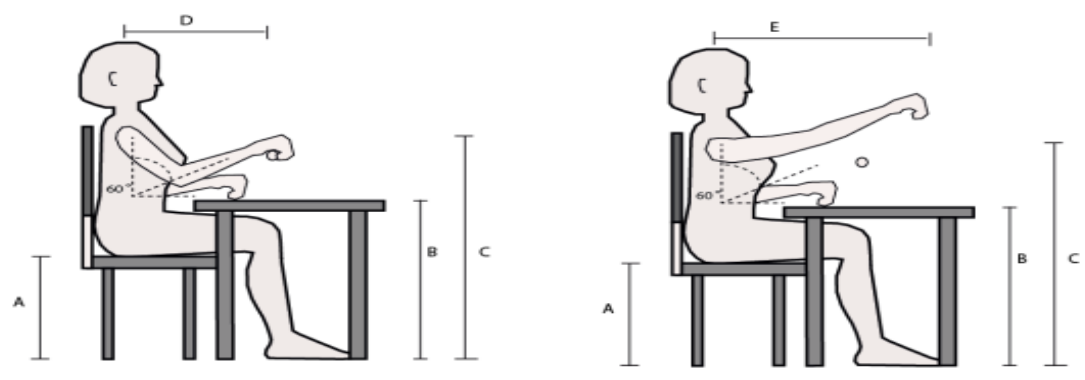

Figure 6. Normal arm reach and farthest arm reach

With calculations using body size from the data above, it is determined that the pengacip lever handle

a. Size Height handle $=$ Height of chair + Size of elbow height in sitting position + allowance

Dimensions: elbow height in sitting position, 50th percentile 


\section{International Journal of Applied Sciences and Smart Technologies}

Volume 1, Issue 2, pages 147-168

p-ISSN 2655-8564, e-ISSN 2685-9432

Allowance: $50 \mathrm{~mm}$

Calculation: $450+187+50=687 \mathrm{~mm}$ (measured from the floor to the maximum height of the handle on the tool. The size obtained from the calculation is the normal height of the elbow in the sitting position plus the seat height. The maximum angle for the normal position of the arm is $90^{\circ}$. The calculation used 50 th percentile or average value so that all operators can adjust properly.

b. The shortest distance for the handle range of the operator

Dimension: distance from elbow to fingertip

Calculation: $337-69=268 \mathrm{~mm}$. The shortest distance of the handle range of the operator must not be smaller than the length of the forearm.In order to be accommodated by all operators, a 95th percentile is used as the minimum size

c. The farthest distance from the operator

The farthest distance from $=$ legth of fore $a r m+y$

handle

$r \quad=$ shoulder height in a sitting position elbow in a sitting position

$$
y \quad=\cdot \sin 60^{\circ}=300 \times 0.866=260 \mathrm{~mm}
$$

Dimension $\quad=$ shoulder height at sitting position $=515 \mathrm{~mm}$ (average value)

Elbow height at sitting position $=186 \mathrm{~mm}$

Distance from elbow to finger $=297 \mathrm{~mm}$ tip

Female finger length Percentile $=5$

Calculation $\quad=260+258-69=450 \mathrm{~mm}$

The maximum distance reached so that percentile 5 is used so that the operator has it smaller extreme sizes could reach. The upper arm angle with body $60^{\circ}$ because it is the angle for optimal attraction [8].

d. Handle diameter

Handle diameter according to Petrofsky, 1980 in Sritomo W, 2000 optimal size for women is a maximum of $4 \mathrm{~cm}-5 \mathrm{~cm}$. 


\section{International Journal of Applied Sciences and Smart Technologies}

Volume 1, Issue 2, pages 147-168

p-ISSN 2655-8564, e-ISSN 2685-9432

\section{Sketch Design for Modifying the Cashew Peeler}

The method of morphological maps is used to find alternative concepts of the cashew tool design. Selection of alternatives is to choose an alternative concept that is closest to fulfilling the specifications of the tools needed. Mapping parts and components of the tool based on the concept of existing tools on the market. Alternative selection will also consider the criteria established as a reference for choosing alternatives.

Determination of the specifications of the tool is prepared from the needs of the user and identified from the problems in the process of working on the existing tool.Look at Table 7 below :

Table 7. Alternative analysis, morphology chart

\begin{tabular}{|c|c|c|c|c|}
\hline No & Specifications & Category & Aspect & $\begin{array}{c}\text { Code } \\
\text { Specifications }\end{array}$ \\
\hline 1. & Cashew seeds separate from cashew nuts & $\mathrm{D}$ & Function & $\mathrm{A} 1$ \\
\hline 2. & Cashew seeds are not split & $\mathrm{D}$ & Function & $\mathrm{A} 2$ \\
\hline 3. & $\begin{array}{l}\text { the safety of the fingers when peeling } \\
\text { cashew is very important }\end{array}$ & $\mathrm{W}$ & Safety & $\mathrm{B}$ \\
\hline 4. & Power to peel as lightly as possible & $\mathrm{W}$ & Ease to operate & $\mathrm{C} 1$ \\
\hline 5. & $\begin{array}{l}\text { The sheller tool considers the position of } \\
\text { work comfort (ergonomics) }\end{array}$ & $\mathrm{D}$ & Ergonomic & D1 \\
\hline 6. & $\begin{array}{l}\text { The weight of the pengacip tool is no more } \\
\text { than } 16 \mathrm{~kg} \text {, as a limit to women's lifting } \\
\text { ability }\end{array}$ & $\mathrm{W}$ & Ergonomic & D2 \\
\hline 7. & $\begin{array}{l}\text { Production tools are portable so they can be } \\
\text { used anywhere }\end{array}$ & $\mathrm{W}$ & Ease to operate & $\mathrm{C} 2$ \\
\hline 8. & $\begin{array}{l}\text { The tool is easy to maintain, durable and } \\
\text { strong. }\end{array}$ & $\mathrm{W}$ & $\begin{array}{l}\text { Ease to } \\
\text { maintenance }\end{array}$ & $\mathrm{E}$ \\
\hline
\end{tabular}

The latest design uses as reference tool, it is made as a morphological map to make it easier to analyze the components of the design of the tools. Analysis of morphological maps can be used to provide changes and modifications to the shortcomings of the tools used as references. Modification can be a total or partial change. The main need for modification is to meet the needs of users, both in the form of functions and aspects of criteria that are arranged as requirements for criteria or specifications. Modification is an innovation that is applied as an alternative design concept at Table 8. 


\section{International Journal of Applied Sciences and Smart Technologies}

Volume 1, Issue 2, pages 147-168

p-ISSN 2655-8564, e-ISSN 2685-9432

Table 8. Analysis of alternative concepts, morphological charts

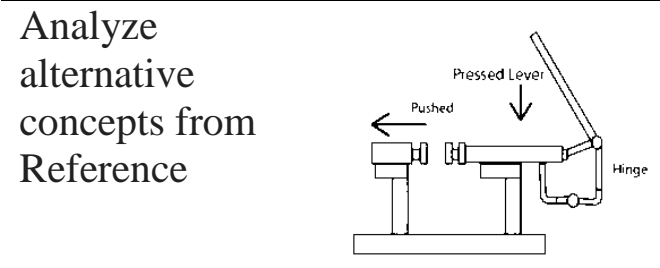

a.

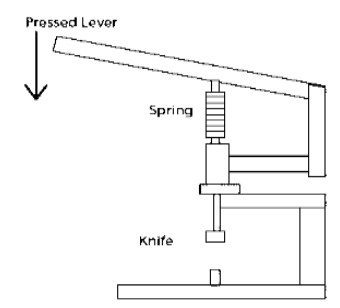

b.

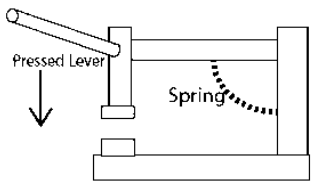

c.
1. Lever

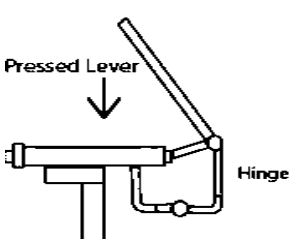

The lever system uses a press hinge and rotates, the arm behind

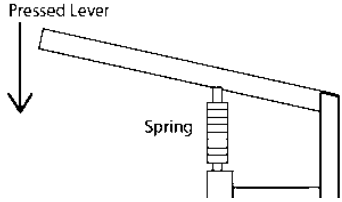

Spring system 1/3 front arm

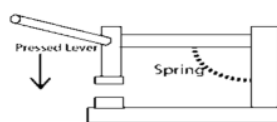

Rear spring system, lever to press on beside

Operational lever angle elbow range $>90^{\circ}$ maximum

Operational lever Operational lever angle elbow range angle elbow range hand reach from the front $>90^{\circ}$, maximum hand $\leq 90^{\circ}$ hand reach reach from the front $\leq 50 \mathrm{~cm}$ from the front
2. $\quad$ Pressing lever

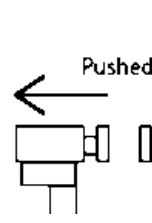

Lever horizontally

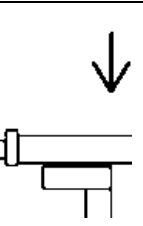

press
The press lever creates a thrust force in the cylinder pressing cylinder horizontally

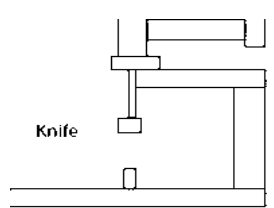

Lever press vertically

Press lever creates a compressive force on the blade pressing lever vertically

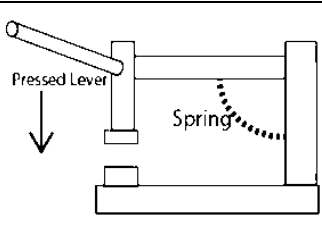

Lever press vertically

Press lever creates a compressive force on the blade pressing lever vertically
3. Blade position and cashing clamp holder

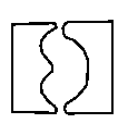

The clamp is in front and at the back, as a knife

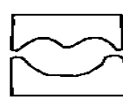

The blade is at the top, the bottom becomes a clamp

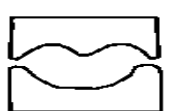

The clamp is at the bottom, the knife is at the top 


\section{International Journal of Applied Sciences and Smart Technologies}

Volume 1, Issue 2, pages 147-168

p-ISSN 2655-8564, e-ISSN 2685-9432

Laying cashew is Laying is easy but not Easy laying, hands difficult because of safe, hands can be hit can be hit by a the position above by a knife knife without restraint

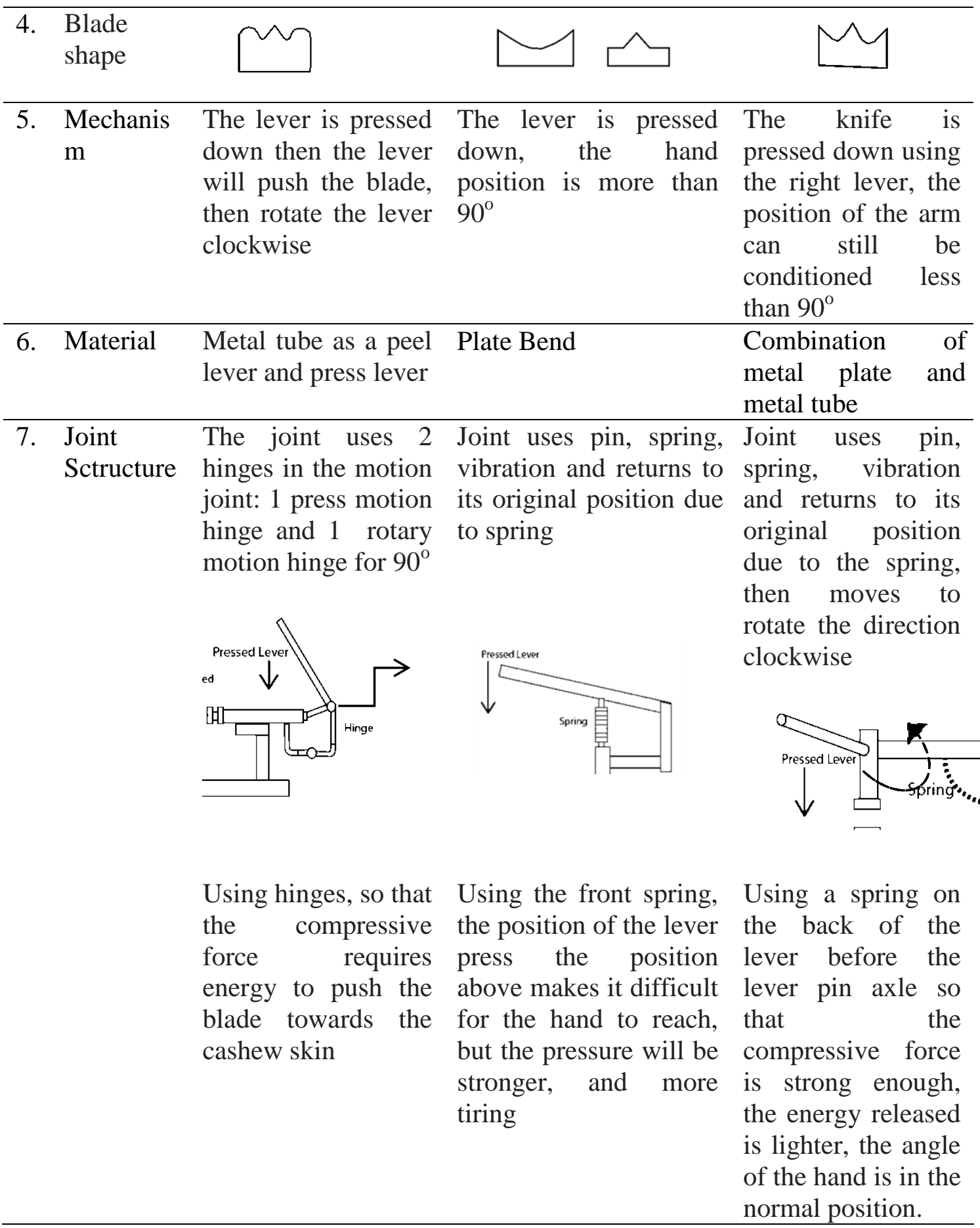




\section{International Journal of Applied Sciences and Smart Technologies}

Volume 1, Issue 2, pages 147-168

p-ISSN 2655-8564, e-ISSN 2685-9432

8. The The operator is in The operator is in front The operator is in direction front with the with the maximum front with a normal of the maximum straight straight range, the elbow operator range, the elbow elbow angle is more towards angle is more than than $90^{\circ}$ the tool $90^{\circ}$

Arranging alternative concepts - alternative designs using a combination of components in the morphological map (see Table 9). Combinations are arranged based on the best possibilities so that they still allow the tool to function properly and meet the requirements of criteria and specifications wherever possible [6].

Table 9. Morphology chart

Notes for symbols in this Table:

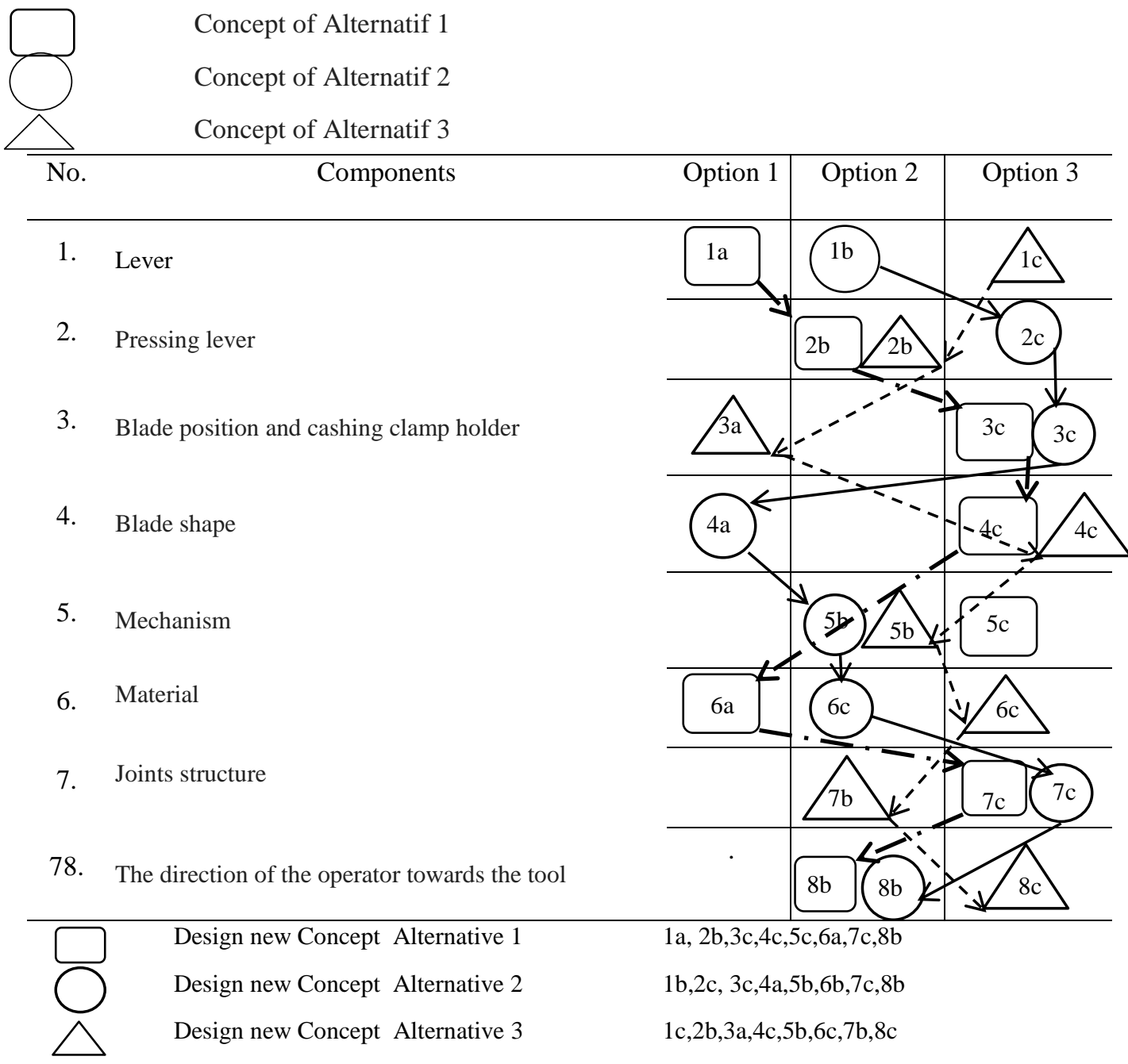




\section{International Journal of Applied Sciences and Smart Technologies}

Volume 1, Issue 2, pages 147-168

p-ISSN 2655-8564, e-ISSN 2685-9432

\section{Results and Discussions of Design Concepts}

The result of this study can be seen in Table 10 below:

Table 10. Analysis of alternative design sketches

\begin{tabular}{|c|c|c|c|c|}
\hline No & Alternative & $\begin{array}{l}\text { Component } \\
\text { combination }\end{array}$ & $\begin{array}{l}\text { Design } \\
\text { sketch }\end{array}$ & $\begin{array}{l}\text { Specification } \\
\text { achievement }\end{array}$ \\
\hline 1. & $\begin{array}{l}\text { Design new } \\
\text { Concept } \\
\text { Alternative } 1\end{array}$ & $\begin{array}{l}\text { 1a, } 2 \mathrm{~b}, 3 \mathrm{c}, 4 \mathrm{c}, 5 \mathrm{c}, 6 \mathrm{a}, 7 \mathrm{c}, 8 \mathrm{~b} \\
\text { The concept of this tool uses } \\
\text { two springs. The working } \\
\text { system presses down with a } \\
\text { spring, then rotates using a } \\
\text { lever used to press the } \\
\text { spring. Lever is in front of } \\
\text { the operator }\end{array}$ & spring & $\begin{array}{l}\text { A1,A2,C1, } \\
\text { D2,C2 } \\
5 \text { criteria are } \\
\text { met from } 8 \\
\text { specification } \\
\text { requirements }\end{array}$ \\
\hline 2. & $\begin{array}{l}\text { Design new } \\
\text { Concept } \\
\text { Alternative } 2\end{array}$ & $\begin{array}{l}1 \mathrm{~b}, 2 \mathrm{c}, 3 \mathrm{c}, 4 \mathrm{a}, 5 \mathrm{~b}, 6 \mathrm{~b}, 7 \mathrm{c}, 8 \mathrm{~b} \\
\text { The concept of this tool uses } \\
\text { one spring. The working } \\
\text { system presses down with a } \\
\text { spring, and then rotates using } \\
\text { another lever on the blade } \\
\text { body. Lever is in front of the } \\
\text { operator. }\end{array}$ & 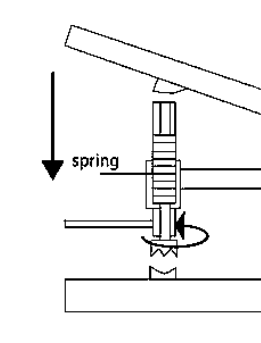 & $\begin{array}{l}\mathrm{A} 1, \mathrm{~A} 2, \mathrm{C} 1, \\
\mathrm{D} 2, \mathrm{C} 2, \mathrm{E} \\
6 \text { criteria are } \\
\text { met from } 8 \\
\text { specification } \\
\text { requirements }\end{array}$ \\
\hline 3. & $\begin{array}{l}\text { Design new } \\
\text { Concept } \\
\text { Alternative } 3\end{array}$ & $\begin{array}{l}1 \mathrm{c}, 2 \mathrm{~b}, 3 \mathrm{a}, 4 \mathrm{c}, 5 \mathrm{~b}, 6 \mathrm{c}, 7 \mathrm{~b}, 8 \mathrm{c} \\
\text { The concept of this tool uses } \\
\text { one spring. The working } \\
\text { system presses down with a } \\
\text { spring, then rotates using a } \\
\text { press lever } \\
\text { The lever is the operator's } \\
\text { farthest range from the front, } \\
\text { but allows the operator to } \\
\text { operate from the right side of } \\
\text { the tool }\end{array}$ & spring & $\begin{array}{l}\mathrm{A} 1, \mathrm{~A} 2, \mathrm{~B}, \mathrm{C} \\
1, \mathrm{D} 2, \mathrm{C} 2, \mathrm{E} \\
7 \text { criteria are } \\
\text { met from } 8 \\
\text { specification } \\
\text { requirements }\end{array}$ \\
\hline
\end{tabular}

\section{Conclusions}

Analysis of alternative sketch drawings - alternative design concepts, is weighted which is judged by the fulfillment of the requirements of the criteria or specifications. The greater value indicates a tendency towards the selection of alternative design concepts. Improvements and improvements must still be made to the chosen design concept. In selected designs the most comfortable position is in front of the operator but normal hand reach with an angle should not exceed 900. Thus the design change is 


\section{International Journal of Applied Sciences and Smart Technologies}

Volume 1, Issue 2, pages 147-168

p-ISSN 2655-8564, e-ISSN 2685-9432

done by changing the handle direction to the side so that the handle range can be carried out in the normal position in Figure 7.

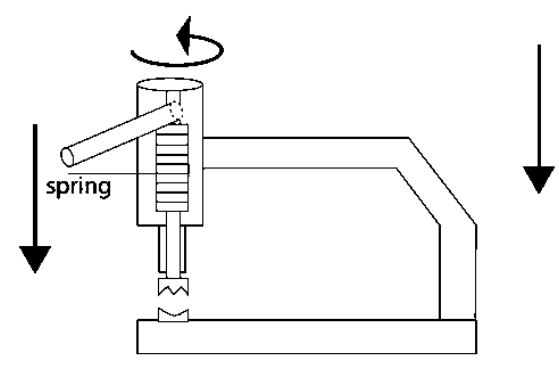

Figure 7. The draft concept was chosen as a peeler with a change in handle direction

The design of the cashew nut peeler is operated manually. The design of the tool size uses the anthropometric measurements of the female operator's body. Improvements in the comfort of work, namely by working in a sitting position, while the tool is placed on the work table. With the facing position from the front, at least the hands are better protected from the danger of being cut by a knife. The lever is located at the normal elbow position, so that the range meets ergonomic work comfort standards. Range of press levers. The way to operate this tool is to use the right hand to move the press lever, then the press lever is moved clockwise to help leverage the cashew seeds out of the cashew nut. The tool is protected with a cover that ensures safety, ease of cleaning and maintenance of the tool.

The weight of the tool is estimated by choosing the right material so that the weight of the tool becomes lighter For the improvement of the design the next opportunity is the flexibility of the tool so that the tool can be adjusted to the work table and the seating position of all operators comfortably. With the concept of this tool design, the tool is expected to be easy to use and safe so that female workers at Ngudi Koyo UKM can work more effectively and efficiently. 


\section{International Journal of Applied Sciences and Smart Technologies}

Volume 1, Issue 2, pages 147-168

p-ISSN 2655-8564, e-ISSN 2685-9432

\section{References}

[1] Badan Pusat Statistik, Kabupaten Bantul dalam Angka, Badan Pusat Statistik Kabupaten Bantul, 2018.

[2] Awaludin, Dace. Modifikasi dan Uji Performansi Alat Pengupas Kulit Buah Mete, Fakultas Teknologi Pertanian, Institut Pertanian Bogor, Bogor, 1995.

[3] Direktorat Jendral Perkebunan, Pedoman Pelaksanaan Pengembangan Jambu Mete, Departemen Pertanian, Jakarta, 1979.

[4] N. Cross, "Engineering Design Methods", John Wiley \& Sons, Chichester, 2008.

[5] M. S. Wibowo, Modifikasi dan Uji Performansi Alat Pengupas Kulit Buah Mete Gelondong, Departemen Teknik Mesin dan Biosistem, Fakultas Teknologi Pertanian, Institut Pertanian Bogor, Bogor, 2011.

[6] E. Lutters, F. J.A.M. van Houten, A. Bernard, E. Mermoz, C. S. L. Schutte, "Tools and techniques for product design," CIRP Annals, 63 (2), 607-630,2014.

[7] S. Ramadhan, Haniza, "Ergonomic facility design on station CV putra darma sorting," Journal of Industrial and Manufacturing Engineering, 1 (1), 46-55, 2017.

[8] S. Wigjosoebroto and Sutaji, "Analisa dan Redesain Stasiun Kerja Operasi Tenun secara Ergonomi untuk Meningkatkan Produktivitas," Seminar Nasional Ergonomi, Teknik Industri FTI-ITS, Surabaya. 2000. 
International Journal of Applied Sciences and Smart Technologies

Volume 1, Issue 2, pages 147-168

p-ISSN 2655-8564, e-ISSN 2685-9432

This page intentionally left blank 